\section{Research Square}

Preprints are preliminary reports that have not undergone peer review.

They should not be considered conclusive, used to inform clinical practice, or referenced by the media as validated information.

\title{
Changes in Blood Pressure After Pfizer/Biontech Sars-Cov-2 Vaccination
}

Chin Chin Ch'ng ( $\nabla$ chngchinchin@gmail.com)

Clinical Research Centre: Institut Penyelidikan Klinikal https://orcid.org/0000-0001-9716-9061

Loke Meng Ong

Penang General Hospital: Hospital Pulau Pinang

Khar Ming Wong

Penang General Hospital: Hospital Pulau Pinang

\section{Research Article}

Keywords: Hypertension, blood pressure, SARS-Cov-2, Covid-19, mRNA vaccine

Posted Date: March 2nd, 2022

DOI: https://doi.org/10.21203/rs.3.rs-1018154/v1

License: (1) This work is licensed under a Creative Commons Attribution 4.0 International License.

Read Full License 


\section{Abstract}

The SARS-Cov-2 (COVID-19) vaccination began in Malaysia in March 2021 among healthcare workers and other frontliners. Everyone at our hospital received the Pfizer/BioNTech mRNA vaccine. Although hypertension has not been mentioned explicitly as an adverse event, concerns were raised after some healthcare staff observed an increase in their blood pressure after the first dose. In response to that, we began collecting vital signs during second dose appointments. Vital signs were measured before, immediately after and 15-30 minutes post vaccination. We report our findings from the institution-wide effort to monitor changes in blood pressure among its staff and respond to any possible unwanted events.

\section{Main Text}

The SARS-Cov-2 (COVID-19) vaccination in Malaysia began in March 2021 among healthcare workers and frontliners. In preparation for the program, our hospital collected information on demographics, comorbidities and willingness to be vaccinated among all its healthcare and essential workers using an online survey.

Vaccination at our hospital began on March 1. Everyone received the Pfizer/BioNTech vaccine. By the end of the month, 4904 staff members had received at least one dose (1225 completed two doses distanced 21 days apart, while another 3679 had yet to receive their second dose). Although hypertension has not been mentioned explicitly as an adverse event(1), concerns were raised after some healthcare staff observed an increase in their blood pressure post vaccination.

In response to that, we began collecting vital signs during second dose appointments. Vital signs were measured three times for each staff member using automated blood pressure monitors that have been calibrated by the vendor of the machines. With the exception of emergencies where the subjects were in a supine pose, all blood pressures were measured in a seated position with the cuff on the arm that was not vaccinated.

Pre-vaccination vital signs were recorded when the staff members arrived at the vaccination site, while post-vaccination vital signs were measured immediately after vaccination and again 15-30 minutes later in a waiting room. They were allowed to leave if their vitals were stable and if they had no complaints. As there was a high load of subjects at the site, vital signs measured immediately post-vaccination were actually delayed by a few minutes. For the same reason, we could not afford to monitor for delayed or extended effects on blood pressure.

Characteristics of the subjects are shown on Table 1. Most of the subjects did not report any adverse effects from both first and second doses. Among those who experienced adverse effects, $84.5 \%$ claimed the severity was worse for the second dose. The most common adverse effects were redness, pain or swelling at the injection site, tiredness, fever, chills, headache and myalgia. 
Table 1

Characteristics of subjects, $n=4906$

\begin{tabular}{|ll|}
\hline Characteristics & \\
\hline Age in years, mean (SD) & $33.6(8.3)$ \\
\hline Females, $\mathrm{n}(\%)$ & $3074(62.7)$ \\
\hline Current smokers, $\mathrm{n}(\%)$ & $370(7.5)$ \\
\hline History of serious allergic reaction, $\mathrm{n}(\%)$ & $309(6.3)$ \\
\hline History of confirmed SARS-CoV-2 infection, $\mathrm{n}(\%)$ & $51(1.0)$ \\
\hline History of comorbidities, n (\%) & $244(5.0)$ \\
\hline Hypertension & $141(2.9)$ \\
\hline Diabetes mellitus & $18(0.4)$ \\
\hline Hyperlipidaemia & $207(4.2)$ \\
\hline Asthma & $43(0.9)$ \\
\hline Cardiovascular disease & \\
\hline Baseline (pre-vaccination) blood pressure in mmHg, mean (SD) & $130.1(17.38)$ \\
\hline Systolic & $80.2(11.62)$ \\
\hline Diastolic & \\
\hline SD standard deviation & \\
\hline
\end{tabular}

Mean pre-vaccination systolic and diastolic blood pressures were 130.1 (SD 17.38) $\mathrm{mmHg}$ and 80.2 (SD 11.62) $\mathrm{mmHg}$, respectively. Both systolic and diastolic blood pressures were significantly higher among those with underlying hypertension compared with those without (SBP difference: 19.9 (95\% Cl 17.77, 22.0) $\mathrm{mmHg}, \mathrm{p}<0.001$; DBP difference: 8.9 (95\% Cl 7.58, 10.29) $\mathrm{mmHg}, \mathrm{p}<0.001)$.

Compared with baseline, blood pressure was increased in more than half of the subjects immediately and 30 minutes post vaccination. The mean changes across all measures were highly significant, but the difference may not be clinically important. When we looked at those with hypertension $(n=244)$, paired ttests revealed that only increases in diastolic blood pressure were significant (Table 2). 
Table 2

Changes in blood pressure immediately and 15-30 minutes after vaccination compared with baseline (pre-vaccination)

$\begin{array}{lll}\text { Blood pressure } & \begin{array}{l}\text { Immediately after vaccination } \\ \text { compared with baseline }\end{array} & \begin{array}{l}15-30 \text { minutes after vaccination } \\ \text { compared with baseline }\end{array}\end{array}$

\section{Mean systolic change $(95 \% \mathrm{Cl}), \mathrm{mmHg}$}

$\begin{array}{lll}\text { All subjects, } \mathrm{n}=4906 & 2.3(1.95,2.66) * * & 1.1(0.76,1.48) * * \\ \begin{array}{l}\text { Subjects with } \\ \text { hypertension, } \mathrm{n}=244\end{array} & 1.4(-0.41,3.26) & -1.0(-2.87,0.91) \\ \begin{array}{l}\text { Subjects with } \\ \text { cardiovascular disease, } \mathrm{n} \\ =43\end{array} & 3.8(0.28,7.39) * & 2.0(-1.78,5.74)\end{array}$

\section{Mean diastolic change (95\% Cl), $\mathrm{mmHg}$}

$\begin{array}{lll}\text { All subjects, } \mathrm{n}=4906 & 2.4(2.13,2.68) * * & 2.2(1.87,2.43) * * \\ \begin{array}{l}\text { Subjects with } \\ \text { hypertension, } \mathrm{n}=244\end{array} & 3.1(1.58,4.51) * * & 2.2(0.76,3.58) * * \\ \begin{array}{l}\text { Subjects with } \\ \text { cardiovascular disease, } \mathrm{n} \\ =43\end{array} & 1.8(-1.21,4.89) & 2.2(-0.80,5.13)\end{array}$

$S D$ standard deviation

Paired t-test significance: * $p<0.05, * \star p<0.001$

The mean increase in systolic blood pressure immediately post vaccination was significantly lower for females compared to males (1.96 (SD 12.20) vs 3.19 (SD 13.26), $p=0.001)$. There were no significant changes in mean blood pressure among those with history of SARS-Cov-2 infection compared with those without previous exposure to the virus.

Overall, $58(1.02 \%)$ were admitted into the observation room either due to hypertensive urgency or complaints of giddiness. Their mean baseline systolic and diastolic blood pressures were 159.5 (SD 20.19) and 96.4 (SD 12.92), respectively. Ten (17.2\%) had underlying hypertension. Eighteen (31.0\%) whose complications did not improve were transferred to the Emergency Department for further monitoring and treatment as necessary.

Our findings extend similar occurrences that have been reported previously in several European countries to the Asian population(2-5). A recent paper by Bouhanick et al. has suggested a possible increased risk of hypertension with the Pfizer/BioNTech vaccine(6).

Our findings indicated a general increase in blood pressure in more than half of the subjects however, only a small fraction reacted symptomatically. Several mechanisms for hypertension have been 
suggested involving interactions between components of the vaccine and the renin-angiotensin system however they remain hypothetical and causality is yet to be established $(3,6)$. We did not have the manpower to monitor our staff members over a longer term. Thus, it may be in the interest of future studies to observe for extended effects of the vaccine on blood pressure.

In our subjects, history of hypertension or other comorbidities were voluntarily reported and there may be cases where hypertension had been undiagnosed. We also could not rule out pain, stress or other emotional triggers on changes in blood pressure.

Overall, the increases were relatively small and may not prevail over the benefits offered by vaccination. Nevertheless, on the safety side, monitoring of blood pressure and other related symptoms may be warranted to prevent any unexpected serious events.

\section{Declarations}

\section{Ethics approval and consent to participate}

Approval and waiver of informed consent was obtained from the Medical Research and Ethics Committee (MREC) Malaysia (Ref: 21-02036-YOX (2)).

\section{Consent for publication}

Not applicable

\section{Availability of data and materials}

The datasets used and/or analysed during the current study are available from the corresponding author on reasonable request and permission from the hospital.

\section{Competing interests}

The authors declare no competing interests.

\section{Funding}

None

\section{Authors' contributions}

LMO conceptualized the study and acquired the data. KMW did the ground work and acquired the data. CCC cleaned and analysed the data and interpreted the results. CCC was a major contributor in writing the manuscript. LMO and KMW reviewed the article. All authors read and approved the final article. 
We would like to extend our gratitude tothe healthcare team of Hospital Pulau Pinang for their dedication and endless effort in making the vaccination programme and data collection a success. We would also like to thank the Director General of Health Malaysia for his permission to publish this article.

\section{References}

1. Polack FP, Thomas SJ, Kitchin N, Absalon J, Gurtman A, Lockhart S, et al. Safety and Efficacy of the BNT162b2 mRNA Covid-19 Vaccine. N Engl J Med [Internet]. 2020 Dec 10 [cited 2021 Oct 13]; Available from: https://www.nejm.org/doi/10.1056/NEJMoa2034577

2. Meylan S, Livio F, Foerster M, Genoud PJ, Marguet F, Wuerzner G. Stage III Hypertension in Patients After mRNA-Based SARS-CoV-2 Vaccination. Hypertens Dallas Tex 1979. 2021 Jun;77(6):e56-7.

3. Zappa M, Verdecchia P, Spanevello A, Visca D, Angeli F. Blood pressure increase after Pfizer/BioNTech SARS-CoV-2 vaccine. Eur J Intern Med. 2021 Aug;90:111-3.

4. Fournier D, Bouchet $A$, Lebrun-Vignes B. COVID-19 vaccine post-marketing surveillance: Cardiovascular doctors have a role to play! Arch Cardiovasc Dis [Internet]. 2021 Sep 8 [cited 2021 Oct 13]; Available from: https://www.sciencedirect.com/science/article/pii/S1875213621001297

5. Athyros VG, Doumas M. A Possible Case of Hypertensive Crisis With Intracranial Haemorrhage After an mRNA Anti-COVID-19 Vaccine. Angiology. 2021 May 21;00033197211018323.

6. Bouhanick B, Montastruc F, Tessier S, Brusq C, Bongard V, Senard J-M, et al. Hypertension and Covid19 vaccines: are there any differences between the different vaccines? A safety signal. Eur $\mathrm{J}$ Clin Pharmacol. 2021 Aug 7;1-2. 